\title{
Historical and current distribution ranges and loss of mega- herbivores and carnivores of Asia
}

Tariq Mahmood ${ }^{1,2}$, Tuong Thuy Vu ${ }^{3}$, Ahimsa Campos-Arceiz ${ }^{4}$, Faraz Akrim ${ }^{\text {Corresp., }}{ }^{1}$, Shaista Andleeb ${ }^{5}$, Muhammad Farooq ${ }^{1}$, Abdul Hamid ${ }^{1}$, Nadeem Munawar ${ }^{1}$, Muhammad Waseem ${ }^{1}$, Abid Hussain ${ }^{1}$, Hira Fatima ${ }^{1}$, Muhammad Raza Khan ${ }^{1}$, Sajid Mahmood ${ }^{6}$

${ }^{1}$ Department of Wildlife Management, PMAS-Arid Agriculture University Rawalpindi, Rawalpindi 46300, Punjab, Pakistan

2 School of Geography, University of Nottingham Malaysia Campus, Jalan Broga, Semenyih 43500,, Kajang, Selangor,, Malaysia

3 Faculty of Engineering and Science, Curtin University Malaysia., Miri, Sarawak, Malaysia

4 Southeast Asia Biodiversity Research Institute, Xishuangbanna Tropical Botanical Garden, Chinese Academy of Sciences, Xishuangbanna, China

5 School of Resources and Environmental Engineering, Wuhan University of Technology, Wuhan, Hubei Province, China

6 Department of Zoology, Hazara University, Mansehra, Khyber Pakhtunkhwa, Pakistan

Corresponding Author: Faraz Akrim

Email address: farazakrim@uaar.edu.pk

Ecosystem functioning is dependent a lot on large mammals, which are, however, vulnerable and facing extinction risks due to human impacts mainly. Megafauna of Asia has been declining for a long, not only in numbers but also in their distribution ranges. In the current study, we collected information on past and current occurrence and distribution records of Asia's megafauna species. We reconstructed the historical distribution ranges of the six herbivores and four carnivores for comparison with their present ranges, to quantify spatially explicit levels of mega-defaunation. . Results revealed that historically the selected megafauna species were more widely distributed than at current. Severe range contraction was observed for the Asiatic lion, three rhino species, Asian elephant, tigers, and tapis. Defaunation maps generated have revealed the vanishing of megafauna from parts of the East. Southeast, and Southwest Asia, even the protected Areas losing up to eight out of ten megafaunal species. These defaunation maps can help develop future conservation policies, to save the remaining distribution ranges of large mammals. 
1 Revised manuscript No. (\#2020:08:51718:0:1: REVIEW) dated: $23^{\text {rd }}$ November 2020

2 Name of Journal: PeerJ

3 Type of Article: Research Article

4 Title:

5 Historical and current distribution ranges and loss of mega-herbivores and carnivores of Asia

6 Short Title: Rapid decline in mega-gardeners and predators

\section{Authors:}

8 Tariq Mahmood ${ }^{1,2}$, Tuong Thuy $\mathrm{Vu}^{3}$, Ahimsa Campos-Arceiz ${ }^{4}$, Faraz Akrim ${ }^{1}$, Shaista Andleeb ${ }^{5}$,

9 Muhammad Farooq $^{1}$, Abdul Hamid ${ }^{1}$, Nadeem Munawar ${ }^{1}$, Muhammad Waseem ${ }^{1}$, Abid Hussain ${ }^{1}$,

10 Hira Fatima $^{1}$, Muhammad Raza Khan ${ }^{1}$, Sajid Mahmood ${ }^{6}$

11 Affiliations:

$12{ }^{1}$ Department of Wildlife Management, PMAS-Arid Agriculture University Rawalpindi 46300, 13 Punjab, Pakistan.

$14{ }^{2}$ School of Geography, University of Nottingham Malaysia Campus, Jalan Broga, Semenyih 15 43500, Kajang, Selangor, Malaysia.

$16{ }^{3}$ Faculty of Engineering and Science, Curtin University Malaysia., Miri, Sarawak, Malaysia

174 Southeast Asia Biodiversity Research Institute, Xishuangbanna Tropical Botanical Garden,

18 Chinese Academy of Sciences, Xishuangbanna, China

$19{ }^{5}$ School of Resources and Environmental Engineering, Wuhan University of Technology, Wuhan,

20 Hubei Province, China

$21{ }^{6}$ Department of Zoology, Hazara University, Mansehra, Khyber Pakhtunkhwa, Pakistan

22 Numbers of Tables: 03

23 Numbers of Figures: 04

$24 *$ Corresponding author

25 Dr. Faraz Akrim, Lecturer, Department of Wildlife Management,

26 PMAS Arid Agriculture University, Rawalpindi, Pakistan

27 Email: farazakrim@hotmail.com; farazakrim@uaar.edu.pk ;Contact: Cell\#: +92-3005419232

28 Competing interests: Authors have no competing interests to declare 


\section{Abstract}

31 Ecosystem functioning is dependent a lot on large mammals, which are, however,

32 vulnerable and facing extinction risks due to human impacts mainly. Megafauna of Asia has been

33 declining for a long, not only in numbers but also in their distribution ranges. In the current study,

34 we collected information on past and current occurrence and distribution records of Asia's

35 megafauna species. We reconstructed the historical distribution ranges of the six herbivores and

36 four carnivores for comparison with their present ranges, to quantify spatially explicit levels of

37 mega-defaunation. . Results revealed that historically the selected megafauna species were more

38 widely distributed than at current. Severe range contraction was observed for the Asiatic lion, three

39 rhino species, Asian elephant, tigers, and tapis. Defaunation maps generated have revealed the

40 vanishing of megafauna from parts of the East. Southeast, and Southwest Asia, even the protected

41 Areas losing up to eight out of ten megafaunal species. These defaunation maps can help develop

42 future conservation policies, to save the remaining distribution ranges of large mammals.

43 Keywords: Large herbivore, large carnivores, mega-defaunation, mega-gardners, distribution 44 range 


\section{Introduction}

Megafauna species - the largest vertebrates (Hansen \& Galetti, 2009)- were once present in most terrestrial ecosystems (Smith et al., 2010), where they play key roles in the top-down regulation of ecosystem processes. Megafaunal loss results in trophic cascades with large-scale impacts (Estes et al., 2011). The regional loss of megaherbivores, for example, has been linked to changes in nutrient biogeochemistry (Doughty, Wolf \& Malhi, 2013), climate (Doughty, Wolf \& Field, 2010), and seed dispersal processes (Janzen \& Martin, 1982; Campos-Arceiz \& Blake, 2011), among others. The loss of apex predators such as wolves in North America has also been linked to changes in vegetation, pollination, and even local geomorphology (Beschta \& Ripple, 2012). For these reasons, megafauna is often described as a keystone (Owen -Smith, 1989), strongly interacting (Soule et al., 2005), or ecosystem engineering (Campos-Arceiz, 2009) species. But, due to their high resource requirements and tendency to be k-strategists, megafauna species also tend to be very sensitive to human impacts (mainly hunting and habitat loss) and are particularly prone to local and global extirpation (Woodroffe \& Ginsberg, 1998; Milner-Gulland et al., 2003; Cardillo et al., 2005).

There is indeed a long history of megafauna extirpation by humans. The first global wave of human-driven megafaunal extinctions occurred during the Quaternary period, approximately 50,000 to 10,000 years ago (Bonnichsen, 1988; Barnosky, 2008; Smith et al. 2018). This Quaternary Mass Extinction (QME) event was eliminated without replacement about two-thirds of all mammalian genera and one-half of all species having a body mass greater than $44 \mathrm{~kg}$ (Barnosky, 2008). Since the Middle Pleistocene (781 to 126 thousand years ago) the majority of terrestrial ecosystems outside Africa have lost megafaunal vertebrates greater than $44 \mathrm{~kg}$ body mass (Corlett, 2013). However, the QME event had differential effects across continents - 
69 whereby the Americas and Australia lost almost all their megafauna and Africa suffered no major

70 losses, Asia suffered a mild effect, probably due to the long presence of Homo erectus (since $~ 1.6$

71 mya) in the region.

72 The global anthropogenic changes caused by the growth of the human population and 73 geographical distribution, coupled with increased technological capacity in the past few centuries

74 have resulted in another wave of megafaunal decline. Factors including, hunting, habitat 75 fragmentation, habitat loss, human-wildlife conflict, and various anthropogenic activities have 76 accelerated megafauna loss rates.

77 Understanding and quantification of historic ranges of threatened megafauna is a prerequisite 78 for the development of conservation and restoration policies (Laliberte \& Ripple, 2004). Laliberte and Ripple (2004) assessed changes in the distribution range of 43 North American carnivores and ungulates since the 19th century and reported a loss of species richness and range contraction of $>$ $8120 \%$ in about one-third of the species. Ceballos and Ehrlich (2002) reported that among 173 threatened mammals from six different continents, have lost greater than $50 \%$ of their distribution ranges during the past two centuries.Globally, it is estimated that $<21 \%$ of the earth's terrestrial surface has an intact assemblage of large mammals $(>20 \mathrm{~kg}$ ) (Morrison et al., 2007). The Indomalayan region, having a great diversity of large mammals (Soberón \& Ceballos, 2011; Ripple et al., 2016) has faced mammal decline (Ceballos \& Ehrlich, 2002; Sodhi et al., 2010; Ripple et al., 2017) and has only maintained of intact large-mammal assemblage $1 \%$ on its terrestrial area (Morrison et al., 2007). Earlier studies have documented range contractions over time ranging from 89 decades (Worm \& Tittensor, 2011) to a few centuries (Laliberte \& Ripple, 2004; Ceballos \& Ehrlich, 2006; Morrison et al., 2007). The decline in Megafauna has been taking place in parts of 91 tropical Asia, for several millennia (Elvin, 2004). 
The purpose of this study was to record the historical distribution of Asia's megafauna over

93 a period of approximately 10,000 years to identify the level of 'mega-defaunation' across the

94 region and identify priority areas for conservation action. Specifically, our objectives were to (1)

95 collect data on the historical distribution ranges of selected Asian megafaunal species; (2) compare

96 their historical and current distribution ranges; and (3) quantify megafaunal species loss in natural

97 habitats, represented here by the network of Protected Areas (PAs) in the region. Our study

98 provides spatially explicit information on 'mega-defaunation' levels that can be used in the design

99 of conservation policies, particularly for the restoration of megafaunal populations and their

100 ecological function.

\section{Materials and Methods}

102 Geographical and Temporal Scope

103 The geographical scope of our analyses was 'Asia' in senso lato. Specifically, we considered

104 mainland Asia up to approximately $35^{\circ}$ west and $40^{\circ}$ north (we are aware that this is further north

105 than standard tropical limits; e.g. Corlett (2013) and the islands of Sri Lanka, Sumatra, Borneo,

106 Java, Hainan, and Taiwan (Fig. 1a). We consider 'historical distribution' as the natural occurrence

107 of a species anytime in the past $\sim 10,000$ years.

108

109 Species Considered

110 We analyzed variations in the distribution range of ten large mammal species, including six

111 herbivores - the Asian elephant (Elephas maximus), Indian or greater one-horned rhinoceros

112 (Rhinoceros unicornis), Javan or lesser one-horned rhinoceros (Rhinoceros sondaicus), Sumatran

113 or two-horned Asian rhinoceros (Dicerorhinus sumatrensis), gaur (Bos gaurus), and Malayan tapir

114 (Tapirus indicus) - and four carnivores - tiger (Panthera tigris), Asiatic lion (Panthera leo 
115 persica), common leopard (Panthera pardus), and clouded leopard (Neofelis nebulosa; Table 1).

116 These species are a non-exhaustive representation of the largest terrestrial mammals in tropical

117 Asia and their selection was based on their role in the ecosystem including both herbivore and

118 carnivores since both groups have a considerable impact on the ecosystem.

119 Data on Historical and Current Distribution

120 The location data on historical distribution/occurrence of the ten target megafaunal species were

121 collected from published and unpublished literature, our sources included journal articles, books,

122 research thesis, newspaper articles, and personal communications with reputable scientists.

123 Historic location data on the distribution of focal species were collected as described by Mahmood

124 et al., (2019). Data on ecological parameters were also collected including vegetation type,

125 altitude, etc., when available. The articles or records having weak evidence and location data were

126 excluded from the analysis to remove bias and only those sources and records were considered

127 having accurate location data of target species (Mahmood et al., 2019).

128 Location data were then imported into google earth software and saved as KML (keyhole

129 Markup Language) which were then converted into Shapefiles in QGIS (Quantum Geographic

130 Information System) software (Mahmood et al., 2019). The output was a vector layer having a

131 known historical distribution of focal species (blue dots; Fig. 1). Using toggle editor in QGIS

132 software we filled gaps in distribution ranges of species based on previously existing historical

133 maps and ecological factors. During filling gaps in distribution maps the inclusion criteria were if

134 we lacked information related to the historical presence/distribution of a species in an area

135 surrounded by known historical presence and there was no apparent ecological barrier or difference

136 with the surroundings, we considered it as part of the historical distribution range (Mahmood et

137 al., 2019). 
138 The data on the current distribution of nine of the target species (all but Asiatic lions) was

139 downloaded from the website of IUCN's Red List of Threatened Species

140 (http://www.iucnredlist.org/technical-documents/spatial-data) as a shapefile document, which is

141 the most reliable source documenting the current distribution of focal species (Fig. 1).

142 Map of Protected Areas

143 We used the World Database on Protected Areas (https://www.protectedplanet.net/) (UNEP-

144 WCMC, 2015) to map protected areas (PAs) occurring in our study area. The original dataset

145 included more than 8,350 PAs in our area of concern. Of these, we decided to use only terrestrial

146 PAs larger than $20 \mathrm{~km}^{2}$ of size. After excluding small PAs and the category 'marine protected

147 areas', our dataset retained 4,773 PAs, ranging from the $21.1 \mathrm{~km}^{2}$ of Ampang Catchment Forest

148 Reserve (Malaysia) to Bukit Batutenobang NP $\left(8830 \mathrm{~km}^{2}\right)$ in Borneo.

149 Defaunation analyses

150 The historical and current distribution ranges of each species were mapped in the form of dots

151 (past distribution points) and polygons (current distributions as per IUCN data) and a comparison

152 was then made between the historical vs. current occurrence records for each mega-faunal species

153 under study, to highlight the areas that suffered mega-defaunation since historical times.

154 For each species, we constructed past and current distribution range and created a new layer

155 including protected areas classified based on (i) protected areas where focal species were never

156 present, (ii) protected areas where focal species were present in the past but now are extinct, (iii)

157 and protected area where focal species are still present. All analysis was conducted using QGIS

158 software as described by Mahmood et al., (2019).

159 Finally, we summarized the information in four Index maps showing the total number of

160 megafaunal species (from the ten included in our study) historically and currently (2008) present 
161 in the large PAs of tropical Asia; and the absolute and relative loss of megafaunal species per PA.

162 The percent of defaunation in each protected area was simply calculated using:

163

164

165

166

167

168

169

170

172

173

174

175

176

177

178

179

180

181

182

183

184

$$
\underline{\mathrm{D} \times 100}
$$

$\mathrm{H}$

Where, D represents the difference in numbers of megafaunal species in a PA between historical and current times, and $\mathrm{H}$ represents the number of species present in the PA in history. Besides, the total number and size of PAs of Asia were also calculated to assess the percent of PAs that have lost particular megafaunal species during the course of history.

\section{Results}

Initially, we downloaded 2832 occurrence records of megafauna in different forms. After removing duplicate records, we were left with 2450 documents which were further screened and 903 documents were excluded based on weak evidence, and incomplete information. The remaining 1547 articles were further assessed and 237 further articles were removed based on weak evidence and location data to remove bias and the remaining 1310 articles were used for quantitative synthesis and meta-analysis (Figure 1).

\section{Individual species}

\section{Asian elephant}

Asian elephants, in historical times, occurred up to Turkey through west Asia along the Iranian coast; in the Indian subcontinent, China, and spread into Southeast Asia up to Sumatra, Borneo but see Cranbrook et al. (2008) - and Java (Fig. 2). Their historical distribution was reconstructed using 458 points (see OSM for details). The historical distribution records indicate that Asian elephants occurred from northeast China towards the south through Thailand, Cambodia, Vietnam, Malaysia, Sumatra, and Java, while towards the west, it ranged through Bangladesh, Nepal, India, 
185 Pakistan, Iran, and Afghanistan up to Turkey. Whereas currently (Fig.2) its IUCN distribution

186 shows the species occurs in a much-reduced range including Indonesia, Malaysia through

187 Thailand, Bangladesh, China, Nepal, India, and Sri Lanka over an area of approximately 6.9

188 million $\mathrm{km}^{2}$ (Table 1). In the past, Asian elephants were distributed among approximately 2206

189 Protected Areas of Asia measuring approximately 1.2 million $\mathrm{km}^{2}$, whereas at present they occur 190 only in 310 Protected Areas with a total size of approximately 300,000 km² (Fig.2; Table 2).

191 Accordingly, Asian elephants are ecologically missing in $75.2 \%$ of the PAs (or $83.4 \%$ of the PA 192 area) that historically hosted them.

\section{Gaur}

194 The historical range reconstructed in the current study based on 134 points has revealed that

195 historically, gaurs were distributed throughout mainland South and Southeast Asia, from India and

196 Sri Lanka up to the Malay Peninsula (Fig.2). But gaurs are now extirpated from Sri Lanka and in

197 other countries occur in a scattered distribution but still covering an area of approximately 1.5

198 million $\mathrm{km}^{2}$, as per IUCN 2008 distribution maps as against 5.6 million $\mathrm{km}^{2}$ (Table 1; Fig. 2). In

199 terms of protected areas, the species occurred historically in 1818 of the current PAs, whereas at

200 present it occurs in 484 PAs (Table 2; Fig. 2). In terms of protected area size, gaurs have

201 disappeared from approximately $56.1 \%$ of PA's that harbored them in the past (Fig.2; Table 2).

\section{Indian rhino}

203 We reconstructed the historical distribution of Indian rhinos using 36 occurrence points mentioned

204 in the previously published literature, whereby the rhino species ranged in the northern part of the

205 Indian subcontinent, from Pakistan to the India-Burma border, through Nepal, Bangladesh,

206 Bhutan, and southern China (Fig.2). Indian rhinos used to occur in what now would be 465

207 Protected Areas (Table 2). Currently, however, Indian rhinos are restricted to a few small 
208 populations in Nepal and India, occupying an area of 4,193 $\mathrm{km}^{2}$, occurring in 10 PAs (Table 2).

209 Based on their historical distribution, Indian rhinos, are ecologically missing from approximately

$21099.8 \%$ of their historical range and from $95.7 \%$ of PAs where they once occurred (Tables 1 and 2 ;

211 Fig. 2).

\section{Javan rhino}

213 We used a total of 71 location points mentioned in the previously published literature to reconstruct

214 the historical distribution of Javan rhinos, which revealed that they used to occur from Java and

215 Sumatra up to India through the Malay peninsula, Thailand, Cambodia, Laos PDR, Vietnam,

216 Southern China, Myanmar, Bangladesh, Bhutan, and Nepal. (Fig. 2). By 2008, however, Javan

217 rhinos' range was restricted to Cat Tien National Park in Vietnam (a population that sadly went

218 extinct in 2010; Brook et al., (2012), and Java’s Ujung Kulon Peninsula). The species historical

219 range overlapped with 2909 PAs, while by 2008 they were found just in the two PAs as mentioned

220 earlier (Table 1 and 2) sadly only one now (Campos-Arceiz \& Teckwyn, 2019). The Javan rhinos

221 have lost $98.7 \%$ of their historical area that now falls under PAs (Fig. 2; Table 1 and 2).

\section{Sumatran rhino}

223 Sumatran rhinos' historical distribution was reconstructed using 243 location points mentioned in

224 the literature. According to these records, the species ranged from Sumatra and Borneo up to the

225 Himalayan foothills in Bhutan through the Malay Peninsula, Thailand, Cambodia, Lao PDR, 226 Vietnam, southern China, Myanmar, and northeastern India (Fig. 2). Historically, Sumatran rhinos

227 occurred in what is now 2974 PAs, occupying an area of about 1.0 million $\mathrm{km}^{2}$ (PA's), while in 2282008 they were estimated to occur in just 21 PAs having a total area of $15,617 \mathrm{~km}^{2}$ (Fig.2; Table

229 2; unfortunately their range has further reduced and is now limited to four populations in Sumatra 230 and Kalimantan). By the year 2008, their estimated distribution range was approximately 8,880 
$231 \mathrm{~km}^{2}$ (as per IUCN maps). Based on their historical distribution, Sumatran rhinos have disappeared

232 from $98.5 \%$ of the PAs where they historically occurred (Fig.2; Tables 1 and 2).

\section{Asian / Malay tapir}

234 We reconstructed the species historical range using a total of 29 points, according to which, Asian 235 tapirs historically occurred in China, southern Cambodia, southern Vietnam, Lao PDR, Thailand, 236 Myanmar and India, and the Islands of Sumatra, and Java (Fig. 2). At present, however, Asian 237 tapirs are extinct in China, Cambodia, Vietnam, Lao PDR, and India, and the size of their current 238 distribution range (as per IUCN's 2008 map) is only 91,947 km² (Table 1 and 2). Asian tapirs had 239 historically occurred in 1987 current PAs, while at present the species occurs in only 96 PAs 240 (Tables 1 and 2). Hence, Asian tapirs have been lost in approximately $91.2 \%$ of the protected area 241 where they had occurred in history (Fig. 2; Table 2).

243 Tiger

244 Historically, tigers were widely distributed across Asia, from Turkey in the west through South 245 and Southeast Asia up to the eastern coasts of Russia, in the form of 9 subspecies of which only 246 six survive today. Tigers' historical range was reconstructed using a total of 193 location points 247 mentioned in published literature (Fig. 3). However, by 2008 the species was restricted to 13 248 countries including Bangladesh, Bhutan, Cambodia, China, India, Indonesia, Lao PDR, Malaysia, 249 Myanmar, Nepal, Russia, Thailand, and Viet Nam, covering a total distribution range of 250 approximately 1.6 million $\mathrm{km}^{2}$ as per IUCN recent data (Table 1). Historically, tigers were 251 distributed in 4014 PAs covering an area of approximately 2.2 million $\mathrm{km}^{2}$ (as PAs). By 2008, 252 tigers occurred in only 132 PAs with a total PAs size of approximately 0.46 million $\mathrm{km}^{2}$ (Table 2 ). 
253 Therefore, approximately $79 \%$ of the PAs that historically hosted tigers have lost them (Tables 2;

254 Fig. 3).

255 Asiatic lion

256 Fossil records and historical accounts show that in historical times, Asiatic lions ranged from

257 southwest Asia (Iraq, Iran, Pakistan, and India) through eastern India up to North Africa Central

258 Asia (Ukraine, Armenia, Azerbaijan), and Europe (Italy, Greece, Bulgaria, Macedonia, Hungary,

259 Turkey, Russia) (Fig. 3). We used 44 total numbers of location points extracted from published

260 literature to reconstruct this historical distribution in Asia (Table 1). The distribution/location

261 points of Asiatic lions that fall outside of Asia, especially North Africa and Europe, were not

262 included in the current study and analysis. By 2008, this apex carnivore had become confined to a

263 single place: the Gir forest of Gujarat, India, occupying a range size of just 1,412 $\mathrm{km}^{2}$ (Table 2).

264 In the past, this top carnivore species occurred in 892 PAs, covering a size of approximately

$265300,000 \mathrm{~km}^{2}$ (Table 2). Hence, Asiatic lions have disappeared from approximately $99.5 \%$ of the

266 PAs that historically had hosted them (Table 1 and 2; Fig. 3).

267 Common leopard

268 Common leopards historically had a much broader range, occurring in the form of nine subspecies

269 from Turkey into Southwest Asia (including Iran, Afghanistan, Pakistan), Nepal, Bhutan, India,

270 Sri Lanka, Bangladesh, Myanmar, China, North and South Korea, Thailand, Laos, Vietnam,

271 Cambodia, Malaysia and the island of Java; they also occurred in Oman, UAE, Central Asian states

272 and Europe including Turkmenistan, Azerbaijan, Uzbekistan, Georgia, Armenia, and Russia (Fig.

273 3). While still widely distributed, common leopards' range has been constrained to ca 8.4 million

$274 \mathrm{~km}^{2}$ from their historical range (Table 1). Common leopards occurred historically in 4,864 PAs,

275 covering a cumulative protected area of approximately 2.25 million $\mathrm{km}^{2}$ (Table 2). By 2008 they 
276 occurred in $451 \mathrm{PAs}$, having a total size of approximately 1.12 million $\mathrm{km}^{2}$. This is, approximately

$27790 \%$ of the PAs and about $50.2 \%$ PA area that historically had leopards have lost this top predator

278 (Table 2; Fig. 3).

279 Clouded leopard

280 More recently, the clouded leopard has been split up into two distinct species based on genetic 281 analysis; the clouded leopard (Neofelis nebulosa) and the Sunda clouded leopard (Neofelis diardi).

282 Based on a total of 73 location points mentioned in the published literature about occurrence of $N$. 283 nebulosa in the past, we reconstructed its historical distribution range (Fig. 3). The species $N$. 284 nebulosa had a wider distribution in history than the current one - it ranged from India and Nepal 285 up to Peninsular Malaysia through Bangladesh, and China (south of Yangtze) but today, its 286 distribution range has been restricted, and according to IUCN estimates, it covers an area of 287 approximately 2.2 million $\mathrm{km}^{2}$ (Table 1; Fig. 3). The clouded leopard occurred in what is now 2882234 PAs, covering a total area of approximately 0.89 million $\mathrm{km}^{2}$. Today, clouded leopards occur 289 in 813 PAs which cover an area of approximately $400,000 \mathrm{~km}^{2}$ (Table 2). In terms of numbers of 290 PAs, clouded leopards had disappeared from approximately $63.6 \%$ of the PAs and $54.3 \%$ of the 291 PA area that they historically occupied (Table 2; Fig.3). The other species, the Sunda clouded 292 leopard was distributed on Borneo and Sumatra in the past and has not shown much range changes.

\section{General Defaunation Patterns}

294 In whole Asia, a total of 8380 protected areas of various categories occur according to the "world 295 database on protected areas (WDPA)", including marine PAs that were not included in our 296 analysis. Also, we excluded 3577 PAs from the current analysis because of their small size (being 297 less than $20 \mathrm{~km}^{2}$ ). So the total numbers of PA's analyzed in the current study were 4773 , ranging 
298 from $20 \mathrm{~km}^{2}$ to PAs as large as Kerinci Seblat NP $\left(13,750 \mathrm{~km}^{2}\right)$, Sunderban South WLS (36970

$\left.299 \mathrm{~km}^{2}\right)$, Cholistan Game Reserve (20326 km²), and Touran NP (14706 km²; Tables 1 and 2).

300 Historically, a higher number of megafaunal species were present in SE than in SW Asia

301 (Fig.4 A-D). For example, as many as eight out of our ten studied species were expected to have

302 occurred sympatrically in SE Asian PAs such as Taman Nagara NP (Peninsular Malaysia), Tonle

303 Sap Biosphere Reserve (Vietnam), and Nam Chuane Conservation area (Lao PDR). The PAs rich

304 in megafauna outside SE Asia include Royal Bardia NP (Nepal), where also eight megafauna

305 species occurred; Yangzie Nature Reserve (China), with seven species. In South Asia, smaller

306 numbers of megafaunal species co-existed historically (Fig. 4) - e.g. a maximum of six species

307 occurred in Simlipal NP and Kaimur sanctuary (India). Further towards SW Asia, in Iran and Iraq,

308 the number of sympatric species decreases considerably: e.g. three species in Bahukalat and two

309 in Kavir NP Iran (Table 3).

310 The current scenario shows drastic changes in the distribution of Asian megafaunal species

311 (Fig. 4 B-D) - some PAs that should be rich in megafauna have suffered total defaunation. Notable

312 examples include Tonle Sap Biosphere Reserve (Vietnam), which has lost all of its original eight

313 species; Dahongshanyinxing and Poyanghuhouniao Nature Reserves (China), which have lost

314 their seven species; and Wu Ling Yuan (China), which has lost all six species. Noradehi Sanctuary

315 (India) has lost five species; Chumbi Surla WLS, Thal Game Reserve, Nara desert WLS, and

316 Diljabba-Domeli Game Reserve (Pakistan) retain none of the five historical megafauna species;

317 and Dareh Anjir and Neibaz Wildlife Refuge (Iran) have lost all of their original three historical

318 megafauna species (Fig.4 b). Cases of PAs that have lost most of their megafaunal species are

319 much more abundant (Table 3). 
Importantly, none of the PAs in our study have been successful in retaining all their historical

321 megafaunal species, although a few PAs have retained more than $70 \%$ such as Taman Negara NP

322 (Malaysia, retained 6 out of eight species), Kerinci Seblat NP (Indonesia, retained five out of six),

323 and Gunung Leusur NP (Sumatra, retained four out of five; Table 3; Fig. 4). The highest relative

324 defaunation is in Southwest Asia, although the overall number of species loss is smaller than in

325 other areas.

326 Discussion

327 This is, to our knowledge, the first attempt to produce a spatially explicit description of megafaunal

328 loss in tropical Asia in historical times. We found that seven of the ten species in our analyses have

329 suffered drastic range reduction in historical times. These are shocking figures that show the dire

330 situation of Asian megafauna and the tendency towards a neotropicalization (a term coined by

331 Richard Corlett) of tropical Asia. Importantly, we show that megafaunal loss has occurred not only

332 in human-dominated landscapes but also in PAs - areas explicitly devoted to the conservation of

333 biodiversity and ecological processes. Our results show a regional-scale case of megafaunal-empty

334 forest (Redford, 1992) and a caveat of the current system of PAs in protecting ecological processes

335 and interactions.

336 Larger species - whether herbivores or carnivores - had larger original distribution ranges

337 and have also suffered the most acute range reductions. This contrasts with the results of Ceballos

338 \& Ehrlich (2002), who found no effect of body size in the range contraction patterns of 173

339 mammal species across the globe. Among megaherbivores, the three rhinoceros species have

340 suffered the most dramatic range reductions, indicating that they are an especially vulnerable clade.

341 Rhinos have been long persecuted in Asia for the medicinal value falsely attributed to their horns

342 (Ellis, 2006). At present, rhinos can be considered ecologically extinct sensu (McConkey \& Drake, 
343 2006) throughout most Asian ecosystems and chances are that within the next few decades

344 Sumatran and Javan rhinos will become extinct, both in the wild and captivity. Such a tragedy

345 would be in line with the trend in the past few decades in which several rhino taxa have been

346 declared extinct in the wild: mainland Javan rhinos in 2010, northern white rhinos in 2010

347 (Ceratotherium cottoni), (Emslie, 2012), and western black rhinos Diceros bicornis longipes in

3482011 (Emslie, 2012). All these taxa were driven to extinction by human persecution. Although an

349 alternative view suggests that rhinos got disappeared from their historical range in China due to

350 mainly climatic factors (Elvin, 2004), we do not think that climate has played an important role

351 compared with hunting and direct human competition for good habitats during the study period.

352 Asian elephants, the largest of Asian terrestrial animals, have shown dramatic range

353 contraction which according to a previous estimate is $>95 \%$ by Sukumar (2006). Most of this loss

354 occurred in southwest Asia (Turkey, Iraq, Iran, Afghanistan, and Pakistan), where elephants

355 disappeared a long time ago (Olivier, 1978) as well as in China, where elephants have been

356 gradually 'retreating' over the past $2.5-3$ thousand years until remaining isolated in a small area

357 of Yunnan's province (Olivier, 1978; Elvin, 2004). Elephants got extinct from Java in the $18^{\text {th }}$

358 century (Cranbrook, Payne \& Leh, 2008). In India, where approximately $60 \%$ of the remaining

359 wild Asian elephant population occurs nowadays (Sukumar, 2006), they have also lost most of the

360 range. In other parts of tropical Asia, the elephant range has become highly fragmented in recent

361 times, e.g. in Sumatra they have recently been declared critically endangered after losing nearly

362 two thirds of the subspecies habitat in one elephant generation (Gopala et al., 2011). Bornean

363 elephants are considered native now.

364 Asian tapirs are one of the few Asian megafaunal species that are not persecuted for Chinese

365 Traditional Medicine (Kawanishi \& Sunquist, Melvin; Othman, 2002), and whose meat is not 
366 popular (especially in Malaysia, where they are considered non-halal, i.e. not permissible food

367 under the Islamic law). For these reasons, there is a general assumption that tapir populations are

368 not under high pressure (Kawanishi \& Sunquist, Melvin; Othman, 2002). Our results, however,

369 reveal a worrying situation with a dramatic reduction of $98 \%$ of their historical range and the

370 complete disappearance from China, Laos PDR, Vietnam, Cambodia, and most of Myanmar and

371 Thailand. Available data suggest that tapirs occur at relatively low densities, at least in Peninsular

372 Malaysia (Rayan et al., 2012). Altogether, this depicts a more negative picture for tapir populations

373 than often assumed.

374 Gaurs show the smallest range contraction among our studied megaherbivores, but this still

375 amounts to almost three-quarters of their original range. Gaurs have probably been intensively

376 hunted for their meat (Choudhury, 2002) throughout most of their range, to the point of being

377 extirpated from Nepal, Bhutan, northern India, Bangladesh, sough China, and much of Indochina

378 and the Malay Peninsula (Fig. 2b). Although the gaur was the only wild bovid included in this

379 study, tropical Asia is home to other large and threatened wild bovids, notably the banteng (Bos

380 javanicus; Endangered), kouprey (Bos sauveii; Critically Endangered and probably extinct),

381 lowland anoa (Bubalus depressicornis; Endangered), mountain anoa (Bubalus quarlesi;

382 Endangered), and the tamaraw (Bubalus mindorensis; Critically Endangered), among others. Most

383 of these species have extremely reduced distribution ranges, often limited to island relic

384 populations. We did not include these species in our analysis due to the difficulty to find

385 information about their historical range.

386 A decline in the density of terrestrial herbivores, in turn, may threaten the largest carnivores

387 like tigers, and the eventual loss of apex predators (trophic downgrading) leads to impacts that

388 may cascade down through the food web. Among the four large carnivores studied, Asiatic lions 
389 lost almost all of their historical range and are now restricted to a single location in the Gir forest

390 of India. Tigers have also got their ranges drastically reduced in history. In the last century alone,

391 three tiger subspecies have been lost: the Caspian (P.t. virgata), Javan (P. t. sondaica), and Bali

392 (P. t. balica) tigers, while the South China tiger (P. t. amoyensis) is probably extinct in the wild.

393 Most of the range loss for tiger occurred in southwest Asia, Central Asia, and China. Sanderson et

394 al. (2006) and Walston et al. (2010) have estimated that tigers lost 93\% of their range, a figure

395 very similar to our estimate in the current study. Much of this decline occurred in the last two

396 centuries as the result of active persecution by colonial rulers. In French Indochina, for example,

397 as many as 45,000 tigers could have been killed between 1860 and 1940 (Guérin, 2010). As many

398 as 8,000 people might have been killed by tigers in Indochina during that same period (M. Guerin

399 pers. comm.).

400 There seems to be a strong gradient of a higher diversity of megafaunal species in mainland

401 East and Southeast Asia that declines towards the west (Fig. 3a). Historically, in some areas of

402 Southeast Asia such as Taman Negara (Peninsular Malaysia) and Tonle Sap Biosphere Reserve

403 (Cambodia) more than six of these megafaunal species occurred. The Himalayan Hills and the

404 islands of Borneo and Sumatra are also areas with particularly high levels of megafaunal presence

405 in historical times. The loss of megafauna has been most severe in parts of Indochina, East Asia,

406 and the Himalayan Hills, where often more than five species of megafauna are missing in the

407 Protected Areas (Fig. 4c).

408 We used Tropical Asia's network of protected areas as a proxy for healthy - or at least 409 conservation-relevant - ecosystems. We found that more than $90 \%$ of tropical Asia's PAs have

410 lost one or more megafauna species. These results coincide with previous studies that point out to

411 tropical Asia, at least Southeast Asia, as a particularly sensitive area in terms of current defaunation 
412 patterns (Ceballos \& Ehrlich, 2002; Morrison et al., 2007; Ripple et al., 2016, 2017). The results

413 of our current study on mega defaunation can be compared with those that have shown that some

414 areas of the world still retain intact mammal assemblages. For example, Morrison et al. (2007)

415 compared the historical range maps of large mammals with their current distribution to determine

416 areas that have retained complete assemblages of large mammals. They have shown that some

417 regions of the world have been successful in keeping their fauna intact, $21 \%$ of terrestrial surface

418 all of the large mammals more than $20 \mathrm{~kg}$ body weight once they contained. They also showed

419 that $12 \%$ of the total area retaining large mammal assemblages are formerly protected, the degree

420 of protection ranging from $9 \%$ in the Palearctic to $44 \%$ in the Indo-Malayan region. However, a

421 key question regarding the loss of megafauna from Protected Areas is whether these species have

422 been lost in these PAs before or subsequently to the establishment of the PAs. As it is evident from

423 the history of Protected Areas established, since Yellow Stone National Park in USA, all Protected

424 areas have brief history (few hundred years at maximum) of establishment, therefore, we cannot

425 establish that megafaunal loss occurred from the protected areas, because after these areas were

426 set out as protected, much more protection was available to the megafaunal species. Therefore, it

427 is evident that megafaunal loss from PA's had already occurred before these areas were set out as

428 Protected Areas.

429 The large reductions in local megafaunal assemblages must have significant consequences

430 for ecosystems. For example, Corlett (2013) showed co-extinctions of parasites and co-extinctions

431 of commensalists and mutualists because host-specific commensalists and mutualists are also

432 vulnerable. Similarly, Campos- Arceiz and Blake (2011) showed that both African (Loxodonta

433 spp.) and Asian elephants have unique roles as long-distance dispersal agents for seeds of all sizes,

434 including those too large for alternate frugivores to swallow. The next largest non-ruminant 
435 mammal in much of Southeast Asia, the Asian tapir, is unlikely to disperse large seeds from large 436 fruits (Campos-Arceiz et al., 2012).

437 The loss of megaherbivores releases some plant resources for surviving competitors but 438 feeding by megaherbivores may sometimes facilitate feeding by smaller species by increased 439 browse availability near the ground (Makhabu, Skarpe \& Hytteborn, 2006). The competitive 440 interactions between predators can be complex and unpredictable but it has been documented that 441 loss of top carnivores as apex predators results in "trophic downgrading (Estes et al., 2011). 442 Megafaunal loss can also affect climate. For example, all mammalian herbivores produce methane 443 (Franz et al., 2011) and that late Pleistocene spike in megafaunal declines resulted in a rapid loss 444 in methane production, consequently triggering the abrupt younger dryas $(12,800-11,500$ B.P. $)$ 445 cooling event (Smith et al., 2010; Smith, Elliott \& Lyons, 2011). However, carbon dioxide appears 446 to be the primary driver of temperature changes at the end of the last glacial period (Shakun et al., 447 2012).

448 Several issues could not be properly addressed in this study. First, we could not include as 449 many species in our study as we have liked. Ideally, we would like to have included more wild 450 bovids (e.g. banteng), large cats (e.g. snow leopard, Uncia uncia), bears, and large primates but 451 were constrained by the availability of historical distribution data. We hope these gaps will be 452 filled up in future studies. Second, the reconstruction of historical ranges was based on data 453 obtained from different sources and the amount and quality of data available were highly variable 454 across species, ranging from 458 historical distribution points for elephants to 29 in the case of 455 tapirs. Our historical ranges likely differ from the real ones and they are more accurate for some 456 species than for others, and for some areas than for others (e.g. depending on the availability of 457 fossil records). Thirdly, we had difficulty in assessing the reliability of some of our historical 
458 records, as well as in assigning geographical locations to some records that were expressed loosely.

459 Moreover, we focus on the loss of megafauna in PAs because much of the non-protected land in

460 tropical Asia has been severely modified and occupied by humans, making it not suitable for the

461 presence of very large, often conflict-prone species, such as elephants and tigers. This is not to say

462 that non-protected areas cannot or should not host megafauna, but it is more difficult to

463 discriminate between areas that are suitable for megafauna and areas that are not. Finally, we also

464 found difficulty in finding an appropriate metric to quantify defaunation since we used just changes

465 in species richness without consideration of the particular species lost. Recent work in objectively

466 quantifying defaunation (Giacomini \& Galetti, 2013) is very promising and we expect more work

467 developing in this direction.

468 How robust are the earlier distribution records compiled here? Some other studies published

469 have reported some biases in this regard, for example, Monsarrat et al (2018) demonstrated spatial

470 biases in reporting historical distributions of large mammals. Also, Monsarrat \& Kerley (2018)

471 also reported taxonomic biases in the historical reporting of large mammals. Therefore, in the

472 current study, we do understand and realize and recognize the risks inherent in such biases and

473 obviously, these may influence the study outcomes. This is especially the case given the absolute

474 paucity of data for some of the species focused in the current study and across such a huge area,

475 as well as the varying socio-political histories (and hence reporting prospects) across their study 476 area.

477 Throughout the world, there is an increasing interest in restoring ecological processes, 478 including the recovery of long-missing wildlife and the ecological processes they are part of 479 (Donlan et al., 2005). With so much range lost by Asian megafauna, conservation objectives 480 should focus not only on protecting extant populations - the main priority - but also on restoring 
481 lost populations and the ecological role of megafauna. Our maps can be used as a tool to prioritize

482 rewilding projects in tropical Asia. Examples of successful rewilding efforts include the

483 reintroduction of beavers throughout much of Europe (Dewas et al., 2012) or wolves in parts of

484 North America (Licht et al., 2010). Rewilding projects exist throughout the world but are more

485 common in temperate latitudes (Fraser, 2009). In Tropical Asia, it seems inevitable to initiate

486 discussions about the feasibility of range recovery of megafaunal species. Captive populations of

487 animals like Asian elephants, tigers, or gaurs are very common and could be used as founders for

488 rewilding. Much of tropical Asia has experienced rapid economic development in recent decades,

489 especially China, and we think the time is ripe for the region to start seriously considering the

490 recovery of its megafauna through rewilding projects.

\section{Conclusion}

492 Our study provides an insight on defaunation/ range contraction of important herbivore and

493 carnivore species and our findings can be used to guide conservation policies, especially for

494 ecological restoration projects. Historically, the selected megafauna species were found more

495 widely distributed than at current. By groups, rhinos showed the most dramatic range changes,

496 followed closely by Asiatic lions, tapirs, tigers, and elephants. Defaunation was extreme in parts

497 of East and Southeast Asia with Protected Areas having lost up to eight megafaunal species.

\section{Funding}

499 No funding was available for this research work.

500

\section{$501 \quad$ Literature Cited}

502 Barnosky AD. 2008. Megafauna biomass tradeoff as a driver of Quaternary and future extinctions. Proceedings of the National Academy of Sciences of the United States of America 105:1154311548. DOI: 10.1073/PNAS.0801918105.

505 Beschta RL, Ripple WJ. 2012. The role of large predators in maintaining riparian plant 
506

507

508

509

510

511

512

513

514

515

516

517

518

519

520

521

522

523

524

525

526

527

528

529

530

531

532

533

534

535

536

537

538

539

540

541

542

543

544

545

546

547

548

549

550

551

communities and river morphology. Geomorphology 157-158:88-98. DOI: 10.1016/j.geomorph.2011.04.042.

Bonnichsen R. 1988. Quaternary Extinctions: A Prehistoric Revolution. Paul S. Martin and Richard G. Klein, editors. University of Arizona Press, Tucson, 1984. $x+892$ pp., figures, tables, references, index. $\$ 65.00$ (cloth). DOI: 10.2307/281165.

Brook SM, van Coeverden de Groot P, Scott C, Boag P, Long B, Ley RE, Reischer GH, Williams AC, Mahood SP, Hien TM, Polet G, Cox N, Hai BT. 2012. Integrated and novel survey methods for rhinoceros populations confirm the extinction of Rhinoceros sondaicus annamiticus from Vietnam. Biological Conservation 155:59-67. DOI: 10.1016/j.biocon.2012.06.008.

Campos-Arceiz A. 2009. Shit happens (to be Useful)! Use of elephant dung as habitat by amphibians. Biotropica 41:406-407. DOI: 10.1111/j.1744-7429.2009.00525.x.

Campos-Arceiz A, Blake S. 2011. Megagardeners of the forest - the role of elephants in seed dispersal. Acta Oecologica 37:542-553. DOI: 10.1016/j.actao.2011.01.014.

Campos-Arceiz A, Teckwyn L. 2019. Speed up hunt for new rhino home. Nature 566:39.

Campos-Arceiz A, Traeholt C, Jaffar R, Santamaria L, Corlett RT. 2012. Asian Tapirs Are No Elephants When It Comes To Seed Dispersal. Biotropica 44:220-227. DOI: 10.1111/j.17447429.2011.00784.x.

Cardillo M, Mace GM, Jones KE, Bielby J, Bininda-Emonds ORP, Sechrest W, Orme CDL, Purvis A. 2005. Evolution: Multiple causes of high extinction risk in large mammal species. Science 309:1239-1241. DOI: 10.1126/science.1116030.

Ceballos G, Ehrlich PR. 2002. Mammal population losses and the extinction crisis. Science 296:904-907. DOI: 10.1126/science.1069349.

Ceballos G, Ehrlich PR. 2006. Global mammal distributions, biodiversity hotspots, and conservation. Proceedings of the National Academy of Sciences of the United States of America 103:19374-19379. DOI: 10.1073/PNAS.0609334103.

Choudhury A. 2002. Distribution and conservation of the Gaur Bos gaurus in the Indian subcontinent. Mammal Review 32:199-226. DOI: 10.1046/j.1365-2907.2002.00107.x.

Corlett RT. 2013. Where are the subtropics? Biotropica 45:273-275. DOI: 10.1111/btp.12028.

Cranbrook E of, Payne J, Leh CMU. 2008. Origin of the Elephants Elephas maximus L. of Borneo. Sarawak Museum Journal 63:1-25.

Dewas M, Herr J, Schley L, Angst C, Manet B, Landry P, Catusse M. 2012. Recovery and status of native and introduced beavers Castor fiber and Castor canadensis in France and neighbouring countries. Mammal Review 42:144-165. DOI: 10.1111/j.13652907.2011.00196.x.

Dinerstein E, Loucks C, Heydlauff A, Wikramanayake E, Bryja G, Forrest J, Ginsberg JR, Klenzendorf S, Leimgruber P, O’Brien TG, Sanderson E, Seidensticker J, Songer M. 2006. Setting Priorities for the Conservation and Restoration of Wild Tigers: 2005-2015. A User's Guide. Wild:1-50.

Donlan J, Greene HW, Berger J, Bock CE, Bock JH, Burney DA, Estes JA, Foreman D, Martin PS, Roemer GW, Smith FA, Soulé ME. 2005. Re-wilding North America. Nature 436:913914. DOI: 10.1038/436913a.

Doughty CE, Wolf A, Field CB. 2010. Biophysical feedbacks between the Pleistocene megafauna extinction and climate: The first human-induced global warming? Geophysical Research Letters 37. DOI: 10.1029/2010GL043985.

Doughty CE, Wolf A, Malhi Y. 2013. The legacy of the Pleistocene megafauna extinctions on

Peer) reviewing PDF | (2020:08:51718:1:2:NEW 23 Nov 2020) 
552

553

554

555

556

557

558

559

560

561

562

563

564

565

566

567

568

569

570

571

572

573

574

575

576

577

578

579

580

581

582

583

584

585

586

587

588

589

590

591

592

593

594

595

596

597

nutrient availability in Amazonia. Nature Geoscience 6:761-764. DOI: 10.1038/ngeo1895.

Ellis R. 2006. Tiger bone \& rhino horn: the destruction of wildlife for traditional Chinese medicine. Choice Reviews Online 43:43-2835-43-2835. DOI: 10.5860/choice.43-2835.

Elvin M. 2004. The retreat of the elephants: An environmental history of China. Yale University Press. DOI: 10.1080/03612759.2004.10526433.

Emslie R. 2012. Ceratotherium simum. In: IUCN 2013. IUCN Red List of Threatened Species. Version 2013.1. <www.iucnredlist.org>. Downloaded on 17 August 2013.

Estes JA, Terborgh J, Brashares JS, Power ME, Berger J, Bond WJ, Carpenter SR, Essington TE, Holt RD, Jackson JBC, Marquis RJ, Oksanen L, Oksanen T, Paine RT, Pikitch EK, Ripple WJ, Sandin SA, Scheffer M, Schoener TW, Shurin JB, Sinclair ARE, Soulé ME, Virtanen R, Wardle DA. 2011. Trophic downgrading of planet earth. Science 333:301-306. DOI: 10.1126/science. 1205106.

Franz R, Soliva CR, Kreuzer M, Hatt JM, Furrer S, Hummel J, Clauss M. 2011. Methane output of tortoises: Its contribution to energy loss related to herbivore body mass. PLoS ONE 6:e17628. DOI: 10.1371/journal.pone.0017628.

Fraser C. 2009. Rewilding the world. Metropolitan Books, NY.

Giacomini HC, Galetti M. 2013. An index for defaunation. Biological Conservation 163:33-41. DOI: 10.1016/j.biocon.2013.04.007.

Gopala A, Hadian O, Sunarto, Sitompul A, Williams A, Leimgruber P, Chambliss SE, Gunaryadi D. 2011. Elephas maximus ssp. sumatranus. In: IUCN 2013. IUCN Red List of Threatened Species. Version 2013.2. <www.iucnredlist.org>. Downloaded on 25 December 2013.

Guérin M. 2010. Européens et prédateurs exotiques en Indochine, le cas du tigre. In Moriceu, J. M., and Madeline P. 2010. Repenser le sauvage grace au retour du loup. Biblioteque du pole rural 2, pp 211-224.

Hansen DM, Galetti M. 2009. The forgotten megafauna. Science 324:42-43. DOI: 10.1126/science. 1172393.

Janzen DH, Martin PS. 1982. Neotropical anachronisms: The fruits the gomphotheres ate. Science 215:19-27. DOI: 10.1126/science.215.4528.19.

Kawanishi K, Sunquist, Melvin; Othman S. 2002. Malayan Tapirs (Tapirus indicus): Far from Extinction in a Malaysian Rainforest. Tapir Conservation 11:23-27.

LALIBERTE AS, RIPPLE WJ. 2004. Range Contractions of North American Carnivores and Ungulates. BioScience 54:123. DOI: 10.1641/0006-3568(2004)054[0123:rconac]2.0.co;2.

Licht DS, Millspaugh JJ, Kunkel KE, Kochanny CO, Peterson RO. 2010. Using Small Populations of Wolves for Ecosystem Restoration and Stewardship. BioScience 60:147-153. DOI: 10.1525/bio.2010.60.2.9.

Mahmood T, Younas A, Akrim F, Andleeb S, Hamid A, Nadeem MS. 2019. Range contraction of snow leopard (Panthera uncia). PLoS ONE 14:e0218460. DOI: 10.1371/journal.pone.0218460.

Makhabu SW, Skarpe C, Hytteborn H. 2006. Elephant impact on shoot distribution on trees and on rebrowsing by smaller browsers. Acta Oecologica 30:136-146. DOI: 10.1016/j.actao.2006.02.005.

McConkey KR, Drake DR. 2006. Flying foxes cease to function as seed dispersers long before they become rare. Ecology 87:271-276. DOI: 10.1890/05-0386.

Milner-Gulland EJ, Bennett EL, Abernethy K, Bakarr M, Bennett E, Bodmer R, Brashares J, Cowlishaw G, Elkan P, Eves H, Fa J, Milner-Gulland EJ, Peres C, Roberts C, Robinson J, Rowcliffe M, Wilkie D. 2003. Wild meat: The bigger picture. Trends in Ecology and 
598

599

600

601

602

603

604

605

606

607

608

609

610

611

612

613

614

615

616

617

618

619

620

621

622

623

624

625

626

627

628

629

630

631

632

633

634

635

636

637

638

639

640

641

642

643

Evolution 18:351-357. DOI: 10.1016/S0169-5347(03)00123-X.

Morrison JC, Sechrest W, Dinerstein E, Wilcove DS, Lamoreux JF. 2007. Persistence of Large Mammal Faunas as Indicators of Global Human Impacts. Journal of Mammalogy 88:13631380. DOI: 10.1644/06-mamm-a-124r2.1.

Olivier R. 1978. Distribution and Status of the Asian Elephant. Oryx 14:379-424. DOI: 10.1017/S003060530001601X.

OWEN-SMITH N. 1989. Megafaunal Extinctions: The Conservation Message from 11,000 Years B.P. Conservation Biology 3:405-412. DOI: 10.1111/j.1523-1739.1989.tb00246.x.

Rayan DM, Mohamad SW, Dorward L, Aziz SA, Clements GR, Christopher WCT, Traeholt C, Magintan D. 2012. Estimating the population density of the Asian tapir (Tapirus indicus) in a selectively logged forest in Peninsular Malaysia. Integrative Zoology 7:373-380. DOI: 10.1111/j.1749-4877.2012.00321.x.

Redford KH. 1992. The Empty Forest. BioScience 42:412-422. DOI: 10.2307/1311860.

Ripple WJ, Chapron G, López-Bao JV, Durant SM, Macdonald DW, Lindsey PA, Bennett EL, Beschta RL, Bruskotter JT, Campos-Arceiz A, Corlett RT, Darimont CT, Dickman AJ, Dirzo R, Dublin HT, Estes JA, Everatt KT, Galetti M, Goswami VR, Hayward MW, Hedges S, Hoffmann M, Hunter LTB, Kerley GIH, Letnic M, Levi T, Maisels F, Morrison JC, Nelson MP, Newsome TM, Painter L, Pringle RM, Sandom CJ, Terborgh J, Treves A, Van Valkenburgh B, Vucetich JA, Wirsing AJ, Wallach AD, Wolf C, Woodroffe R, Young H, Zhang L. 2016. Saving the World's Terrestrial Megafauna. BioScience 66:807-812. DOI: 10.1093/biosci/biw092.

Ripple WJ, Chapron G, López-Bao JV, Durant SM, MacDonald DW, Lindsey PA, Bennett EL, Beschta RL, Bruskotter JT, Campos-Arceiz A, Corlett RT, Darimont CT, Dickman AJ, Dirzo R, Dublin HT, Estes JA, Everatt KT, Galetti M, Goswami VR, Hayward MW, Hedges S, Hoffmann M, Hunter LTB, Kerley GIH, Letnic M, Levi T, Maisels F, Morrison JC, Nelson MP, Newsome TM, Painter L, Pringle RM, Sandom CJ, Terborgh J, Treves A, Van Valkenburgh B, Vucetich JA, Wirsing AJ, Wallach AD, Wolf C, Woodroffe R, Young H, Zhang L. 2017. Conserving the world's megafauna and biodiversity: The fierce urgency of now. BioScience 67:197-200. DOI: 10.1093/biosci/biw168.

Shakun JD, Clark PU, He F, Marcott SA, Mix AC, Liu Z, Otto-Bliesner B, Schmittner A, Bard E. 2012. Global warming preceded by increasing carbon dioxide concentrations during the last deglaciation. Nature 484:49-54. DOI: 10.1038/nature10915.

Smith FA, Boyer AG, Brown JH, Costa DP, Dayan T, Ernest SKM, Evans AR, Fortelius M, Gittleman JL, Hamilton MJ, Harding LE, Lintulaakso K, Lyons SK, McCain C, Okie JG, Saarinen JJ, Sibly RM, Stephens PR, Theodor J, Uhen MD. 2010. The evolution of maximum body size of terrestrial mammals. Science 330:1216-1219. DOI: 10.1126/science. 1194830.

Smith FA, Elliott SM, Lyons SK. 2011. Reply to "Methane and megafauna." Nature Geoscience 4:272. DOI: $10.1038 /$ ngeo1149.

Soberón J, Ceballos G. 2011. Species richness and range size of the terrestrial mammals of the world: Biological signal within mathematical constraints. PLoS ONE 6:e19359. DOI: 10.1371/journal.pone.0019359.

Sodhi NS, Posa MRC, Lee TM, Bickford D, Koh LP, Brook BW. 2010. The state and conservation of Southeast Asian biodiversity. Biodiversity and Conservation 19:317-328. DOI: 10.1007/s10531-009-9607-5.

SOULÉ ME, ESTES JA, MILLER B, HONNOLD DL. 2005. Strongly Interacting Species: Conservation Policy, Management, and Ethics. BioScience 55:168. DOI: 10.1641/0006-

Peer) reviewing PDF | (2020:08:51718:1:2:NEW 23 Nov 2020) 
644

645

646

647

648

649

650

651

652

653

654

655

656

657

658

659

660

661

662

663

664

665

666

667

668

669

670

671

672

673

674

675

676

3568(2005)055[0168:siscpm]2.0.co;2.

Sukumar R. 2006. A brief review of the status, distribution and biology of wild Asian elephants Elephas maximus. International Zoo Yearbook 40:1-8. DOI: 10.1111/j.17481090.2006.00001.x.

UNEP-WCMC I. 2015. Protected planet: the world database on protected areas (WDPA). Cambridge, UK: UNEP-WCMC and IUCN.

Walston J, Robinson JG, Bennett EL, Breitenmoser U, da Fonseca GAB, Goodrich J, Gumal M, Hunter L, Johnson A, Ullas Karanth K, Leader-Williams N, MacKinnon K, Miquelle D, Pattanavibool A, Poole C, Rabinowitz A, Smith JLD, Stokes EJ, Stuart SN, Vongkhamheng C, Wibisono H. 2010. Bringing the tiger back from the brink-the six percent solution. PLoS Biology 8:e1000485. DOI: 10.1371/journal.pbio.1000485.

Woodroffe R, Ginsberg JR. 1998. Edge effects and the extinction of populations inside protected areas. Science 280:2126-2128. DOI: 10.1126/science.280.5372.2126.

Worm B, Tittensor DP. 2011. Range contraction in large pelagic predators. Proceedings of the National Academy of Sciences of the United States of America 108:11942-11947. DOI: 10.1073/PNAS.1102353108.

Figures Detail

Fig. 1. Flow diagram of database searching and screening for meta-analysis

Fig.2. Historical and current distribution ranges of six herbivore megafauna' species in Protected and non-Protected Areas in Asia. A) Asian elephant B) Gaur C) Indian rhino D) Javan rhino E) Sumatran rhino F) Malay Tapir

Fig. 3. Historical and current distribution ranges of four carnivore megafauna' species in

Protected and non-Protected Areas in Asia. A) Asiatic tiger B) Asiatic lion C) Common leopard D) clouded leopard, E) Sunda clouded leopard

Fig. 4. Index maps of ten selected megafauna species A) showing Total numbers of megafauna species in PA's of Asia in history B) Total numbers of megafauna species at current time C) Defaunation index map showing difference in numbers of megafauna species in PA's of Asia 
677 between historic and current times D) Index map showing percent loss of megafauna in PA's of 678 Asia since history.

679 
Figure 1

Flow diagram of database searching and screening for meta-analysis
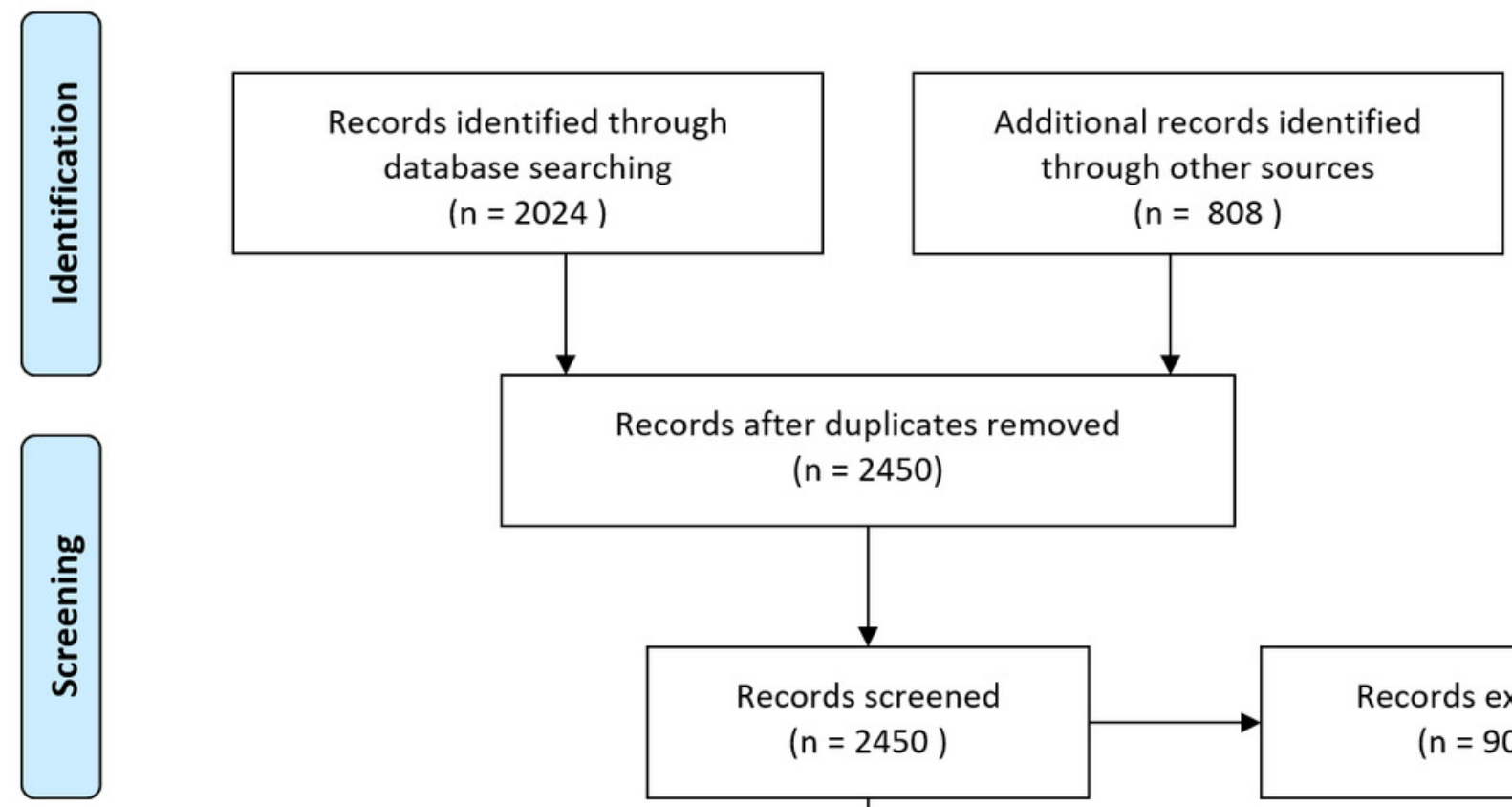

Records after duplicates removed

$$
(n=2450)
$$
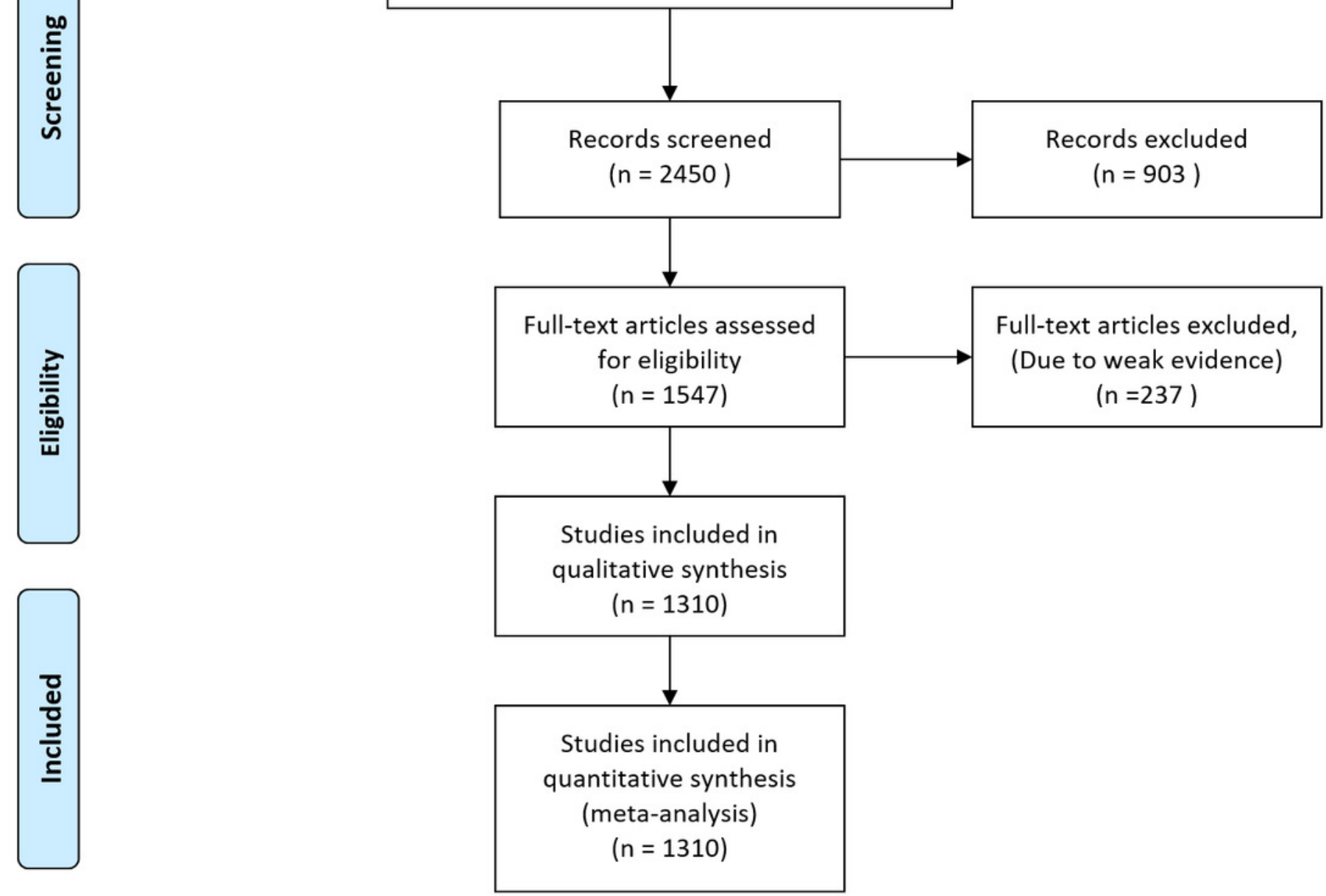
Figure 2

Historical and current distribution ranges of six herbivore megafauna' species in Protected and non-Protected Areas in Asia. A) Asian elephant B) Gaur C) Indian rhino D) Javan rhino E) Sumatran rhino F) Malay Tapir 

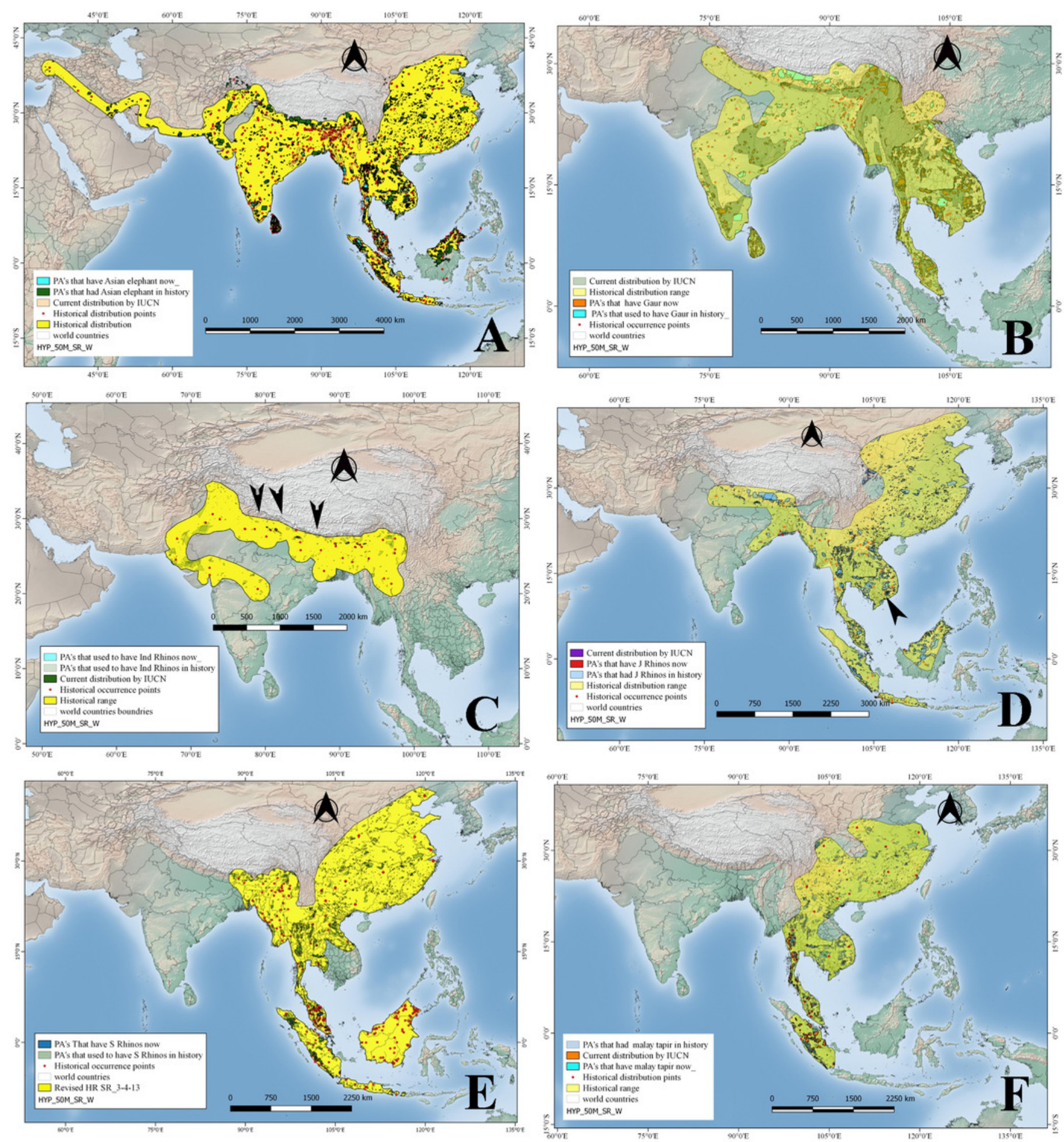
Figure 3

Historical and current distribution ranges of four carnivore megafauna' species in Protected and non-Protected Areas in Asia. A) Asiatic tiger B) Asiatic lion C) Common leopard D) clouded leopard, E) Sunda clouded leopard 

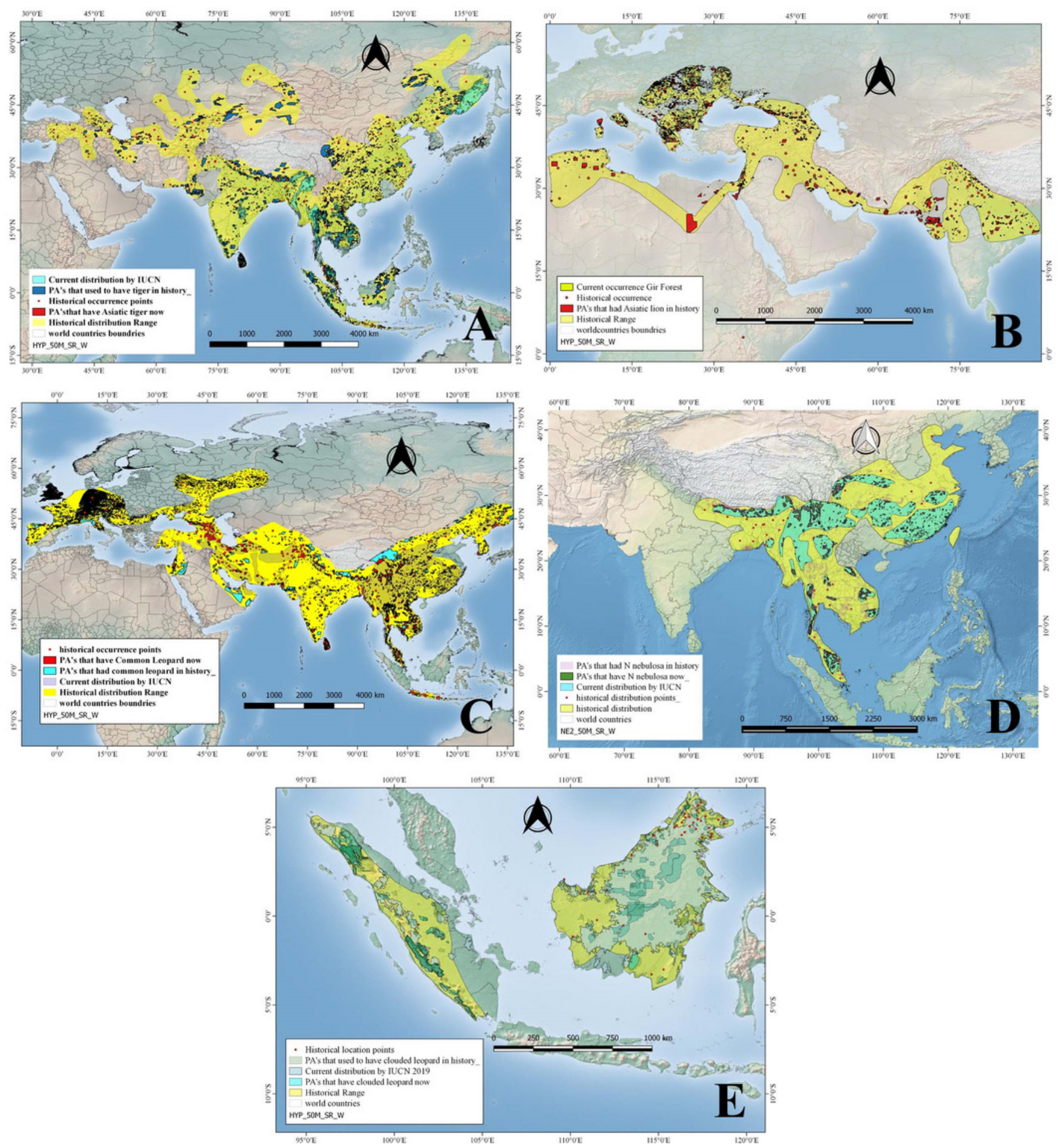
Figure 4

Index maps of ten selected megafauna species A) showing Total numbers of megafauna species in PA's of Asia in history B) Total numbers of megafauna species at current time C) Defaunation index map showing difference in numbers of megafauna species in PA's

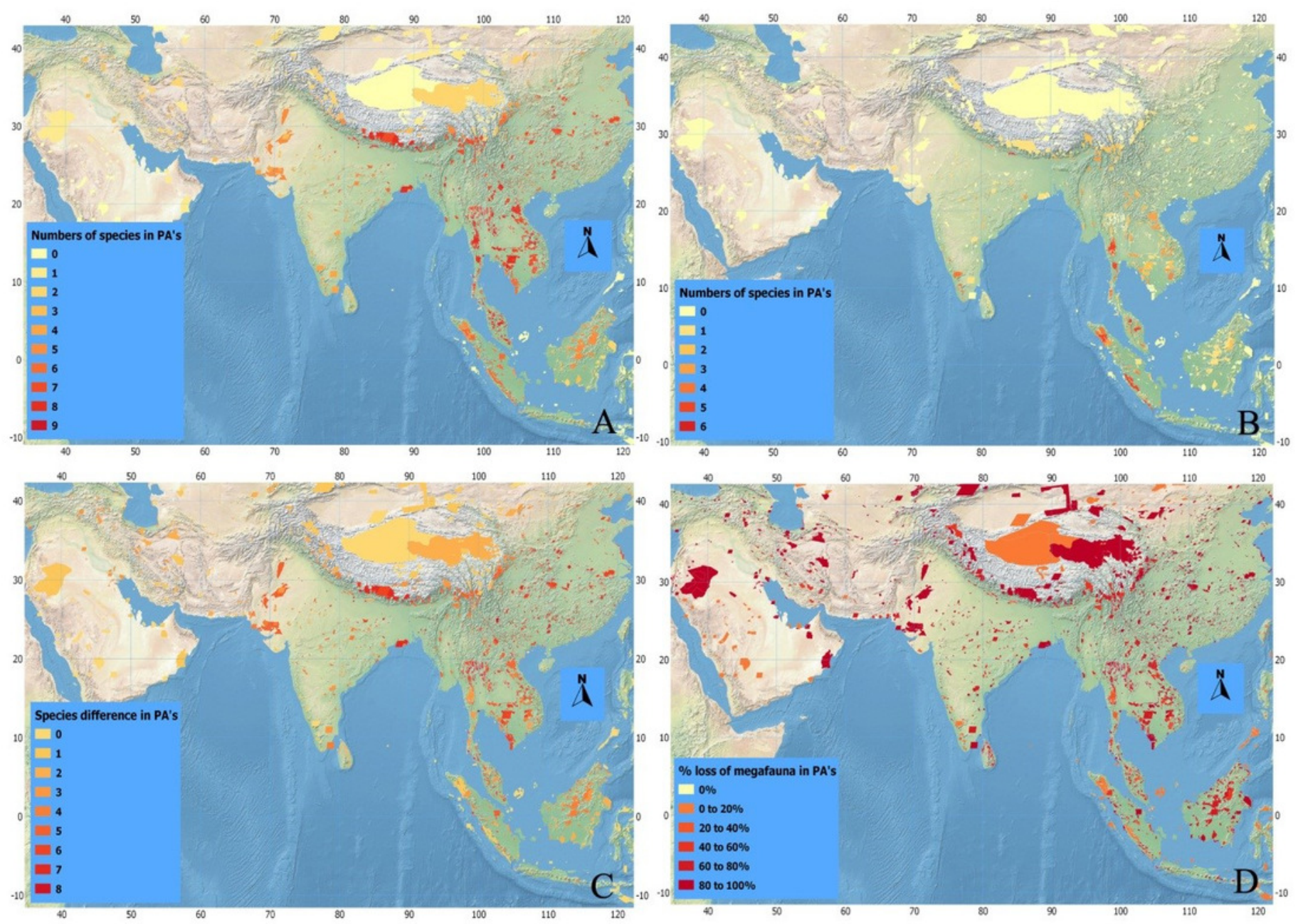




\section{Table 1 (on next page)}

Comparison of historical and current distribution ranges of the ten selected mega-faunal species and percent range reduction that has occurred through history. 
1 Table 1. Comparison of historical and current distribution ranges of the ten selected mega-faunal

2 species and percent range reduction that has occurred through history.

3

\begin{tabular}{|c|c|c|c|c|c|c|}
\hline & Animal species & $\begin{array}{c}\text { Home Range } \\
\text { size } \\
\text { km² }^{2}\end{array}$ & $\begin{array}{c}\text { Maximum } \\
\text { elevation above sea } \\
\text { level }(\mathrm{m})\end{array}$ & $\begin{array}{c}\text { Historical } \\
\text { distribution } \\
{\left(\mathrm{km}^{2}\right)}^{2}\end{array}$ & $\begin{array}{c}\text { Current } \\
\text { distribution } \\
\left(\mathrm{km}^{2}\right)\end{array}$ & $\begin{array}{c}\text { Range } \\
\text { Reduction } \\
\quad(\%)\end{array}$ \\
\hline 1 & Asian Elephant & 320 & 3000 & $1.2 \times 10^{7}$ & $6.9 \times 10^{5}$ & 95.1 \\
\hline 2 & Gaur & - & - & $5.6 \times 10^{6}$ & $1.5 \times 10^{6}$ & 72.0 \\
\hline 3 & Indian Rhinos & - & - & $2.5 \times 10^{6}$ & 4193.2 & 99.8 \\
\hline 4 & Javan Rhinos & - & 2000 & $8.5 \times 10^{6}$ & 252.69 & 100 \\
\hline 5 & $\begin{array}{l}\text { Sumatran } \\
\text { Rhinos }\end{array}$ & 50 & - & $7.5 \times 10^{6}$ & 8879.3 & 99.9 \\
\hline 6 & Malay Tapir & - & - & $4.5 \times 10^{6}$ & 91947 & 98.0 \\
\hline 7 & Asiatic Tiger & 4000 & 4360 & $2.3 \times 10^{7}$ & $1.6 \times 10^{6}$ & 92.9 \\
\hline 8 & Asiatic Lion & - & - & $1.1 \times 10^{7}$ & *1412 & 100 \\
\hline 9 & $\begin{array}{l}\text { Common } \\
\text { Leopard }\end{array}$ & 78 & 5300 & $3.2 \times 10^{7}$ & $8.4 \times 10^{6}$ & 73.7 \\
\hline 10 & $\begin{array}{l}\text { Clouded } \\
\text { leopard }\end{array}$ & - & - & $6.3 \times 10^{6}$ & $2.2 \times 10^{6}$ & 64.0 \\
\hline
\end{tabular}

4

5

6

7

8

9 


\section{Table 2 (on next page)}

Size (area) of protected areas that contained selected mega-faunal species in history and at current times and their percent reduction. 
1 Table 2. Size (area) of protected areas that contained selected mega-faunal species in history and

2 at current times and their percent reduction.

\begin{tabular}{|c|c|c|c|c|c|c|}
\hline \multirow{2}{*}{ Animal species } & \multicolumn{2}{|c|}{$\begin{array}{c}\text { Historical } \\
\text { distribution }\end{array}$} & \multicolumn{2}{|c|}{$\begin{array}{c}\text { Current } \\
\text { distribution }\end{array}$} & \multicolumn{2}{|c|}{ Defaunation } \\
\hline & N PAs & $\begin{array}{r}\text { Area } \\
\left(\mathrm{km}^{2}\right)\end{array}$ & $\begin{array}{c}\mathrm{N} \\
\text { PAs }\end{array}$ & $\operatorname{Area}\left(\mathrm{km}^{2}\right)$ & $\begin{array}{c}\% \text { PAs } \\
\text { (N) }\end{array}$ & $\begin{array}{l}\text { \% PA's } \\
\text { (Area) }\end{array}$ \\
\hline \multicolumn{7}{|c|}{ Mega-herbivores } \\
\hline Asian elephant & 2206 & $1,222,877$ & 310 & 303300 & 83.4 & 75.2 \\
\hline Gaur & 1818 & 793,958 & 484 & 343,468 & 73.4 & 56.1 \\
\hline Indian rhinos & 465 & $2,645,013$ & 10 & 4,193 & 95.7 & 99.8 \\
\hline Javan rhinos & 2909 & $1,156,427$ & 2 & 112 & 99.9 & 100 \\
\hline $\begin{array}{l}\text { Sumatran } \\
\text { rhinos }\end{array}$ & 2974 & $1,016,761$ & 21 & 15,617 & 99.4 & 98.5 \\
\hline Malay tapir & 1987 & 643,009 & 96 & 56,666 & 95.2 & 91.2 \\
\hline \multicolumn{7}{|c|}{ Mega-Carnivores } \\
\hline Asiatic tiger & 4014 & $2,211,656$ & 132 & 463,822 & 96.7 & 79.0 \\
\hline Asiatic lion & 892 & 304,802 & 1 & 1,412 & 99.9 & 99.5 \\
\hline $\begin{array}{l}\text { common } \\
\text { leopard }\end{array}$ & 4864 & $2,249,670$ & 451 & $1,120,815$ & 90.7 & 50.2 \\
\hline clouded leopard & 2234 & 896,598 & 813 & 409,605 & 63.6 & 54.3 \\
\hline
\end{tabular}

$3 *^{*}$ Total Area covered over by PA's of Asia $=7418073.04103 \mathrm{~km}^{2}$

4 Total numbers of PA's of Asia $=8398$

5 


\section{Table 3(on next page)}

Details of the PA's with their size, location, and the numbers of megafauna species they had in history and at current and the percent of defaunation that has occurred in these PA's. 
1 Table 3 Details of the PA's with their size, location, and the numbers of megafauna species they 2 had in history and at current and the percent of defaunation that has occurred in these PA's.

\begin{tabular}{|c|c|c|c|c|c|c|}
\hline $\begin{array}{l}\text { Sr. } \\
\text { No. }\end{array}$ & Name of PA & $\begin{array}{l}\text { Size } \\
\left(\mathrm{km}^{2}\right)\end{array}$ & Country & $\begin{array}{c}\text { No. of } \\
\text { species in } \\
\text { history }\end{array}$ & $\begin{array}{c}\text { No. of } \\
\text { species at } \\
\text { current }\end{array}$ & $\begin{array}{c}\% \\
\text { Defaunation }\end{array}$ \\
\hline 1 & Taman Negara NP & 4524.54 & Malaysia & 8 & 7 & 12.5 \\
\hline 2 & Tonle Sap Biosphere & 3222.69 & Cambodia & 8 & 0 & 100 \\
\hline 3 & Royal Chitwan NP & 750 & Nepal & 8 & 6 & 25 \\
\hline 4 & Gunung Leuser NP & 7926.75 & Indonesia & 5 & 4 & 20 \\
\hline 5 & Kerinci Seblat NP & 13750 & Indonesia & 6 & 5 & 16 \\
\hline 6 & Bukit Batutenobang NP & 8830 & Borneo & 4 & 0 & 100 \\
\hline 7 & Margalla Hills NP & 173.86 & Pakistan & 4 & 0 & 100 \\
\hline 8 & Wu Ling Yuan NP & 264 & China & 6 & 0 & 100 \\
\hline 9 & Yangzie Nature Res & 433.33 & China & 7 & 1 & 85 \\
\hline 10 & Taungup Pass & - & Myanmar & 6 & 2 & 66 \\
\hline 11 & Sunderban South WLS & 36970 & India & 3 & 0 & 100 \\
\hline 12 & Gir Forest NP & 258.71 & India & 3 & 2 & 33 \\
\hline 13 & Yala NP & 289.04 & Sri Lanka & 3 & 1 & 66 \\
\hline 14 & Walpattu NP & 549.53 & Sri Lanka & 3 & 1 & 66 \\
\hline 15 & Wasgomuva & 369.48 & Sri Lanka & 3 & 1 & 66 \\
\hline 16 & Touraun NP & 14706.4 & Iran & 2 & 0 & 100 \\
\hline 17 & Cholistan Game Reserve & 20326.67 & Pakistan & 5 & 0 & 100 \\
\hline 18 & Lang Tang NP & 1710 & Nepal & 7 & 1 & 85 \\
\hline 19 & Ben En NP & 166.34 & Vietnam & 7 & 0 & 100 \\
\hline 20 & Vo Doi NP & 33.94 & Vietnam & 5 & 0 & 100 \\
\hline 21 & Bali Barat & 190.03 & Indonesia & 3 & 0 & 100 \\
\hline 22 & Ujong Kulon NP & 1229.56 & Indonesia & 4 & 2 & 50 \\
\hline 23 & Kota Kinabalu NP & 753.7 & $\begin{array}{c}\text { Saba } \\
\text { Malaysia }\end{array}$ & 4 & 1 & 75 \\
\hline
\end{tabular}




\begin{tabular}{|c|l|c|c|c|c|c|}
\hline 24 & Khao Yai NP & 2165.55 & Thailand & 8 & 3 & 62 \\
\hline 25 & Trishna WLS & 194.7 & India & 8 & 0 & 100 \\
\hline 26 & Wolong NR & 2000 & China & 5 & 1 & 80 \\
\hline 27 & Barail WLS & 300 & India & 7 & 0 & 100 \\
\hline 28 & Rema Kalenga WLS & & $\begin{array}{c}\text { Banglades } \\
\text { h }\end{array}$ & 8 & 0 & 100 \\
\hline 29 & Belum WLR & 2072 & Malaysia & 8 & 6 & 25 \\
\hline 30 & Cat Tien NP & 738.78 & Vietnam & 7 & 4 & 42 \\
\hline 31 & Royal Bardia NP & 968 & Nepal & 8 & 4 & 50 \\
\hline 32 & Kaziranga NP & 849.79 & India & 7 & 4 & 42 \\
\hline 33 & Pegu Yomas NP & 1463.35 & Myanmar & 7 & 3 & 57 \\
\hline 34 & Namdapha NP & 1807.82 & India & 7 & 3 & 57 \\
\hline 35 & Manas NP & 391 & India & 8 & 3 & 62 \\
\hline
\end{tabular}

3

4

5

6

7

8

9 